\title{
The MOORA method for selecting software App: price-quality ratio approach
}

\author{
Akmaludin ${ }^{1)^{*}}$, Erene Gernaria Sihombing ${ }^{2)}$, Linda Sari Dewi ${ }^{3)}$, Rinawati ${ }^{4)}$, Ester Arisawati ${ }^{5)}$ \\ ${ }^{122) 334) 5}$ STMIK Nusa Mandiri, Jakarta, Indonesia \\ ${ }^{1)}$ akmaludin.akm@nusamandiri.ac.id, ${ }^{2}$ erene.egs@ @ nusamandiri.ac.id, ${ }^{3}$ linda.lrw@ nusamandiri.ac.id, \\ 4)rinawati.riw@ nusamandiri.ac.id, ${ }^{5)}$ ester.err@nusamandiri.ac.id
}

Submitted :Nov 18, 2020 | Accepted : Mar 11, 2021 | Published : Apr 1, 2021

\begin{abstract}
Seeing the rapid progress of software app. in today's destructive era, the need for software app. is very reliable for industrial progress in the era of the 4.0 generation. Especially in object-oriented software app. The main objective of this research is to measure the technical capabilities of object-based software app. and to find out the process of selecting the best number of app.software in terms of the appropriate price. Many techniques can be developed in object-based software app. such as class implementation, Inheritance, Encapsulation, Polymorphic, Constructor, Accessor, Mutator, Visibility, Overwrite and Overload. This technique is an advantage of object-based software app. Taking advantage of these advantages causes difficulty in selecting and evaluating software. Indeed, it is very difficult to evaluate software products, because they are qualitative. In order for the assessment to be objective, it requires good method collaboration, thus an objective method is needed in the assessment of the selection of a number of program app. The test was carried out with the Multi Objective Optimization by Ratio Analysis (MOORA) method collaborated with the Price-Quality Ration approach. The results obtained are the selection of object-based software app. that can be done optimally and provide efficiency in the benefits and costs incurred.
\end{abstract}

Keywords: App. Software, Cost-Benefit; Optimum value, MOORA, Price-Quality Ratio.

\section{INTRODUCTION}

The world of industry 4.0 is currently developing very rapidly which is accompanied by the development of research around the world which experiences destructive conditions that are completely uncertain with all the needs of various users, so that research needs are the most important part of the industry (Prasetyo \& Sutopo, 2018) and it must be handled by all agencies both private and government agencies domestically. To answer all user needs, assistance and support for object-based software app is needed. The software application that is needed now is a software application that crosses the object so that it is necessary to do research on the technique used. Objectbased software app are in great demand and favored by many users, because in fact there are features that can be developed (Ayubi et al., 2015) such as making Class, Inheritance, Encapsulation, Pollymorphys, Constructor, Accessor, Mutator, Visibility, Overriding, and Overloading. Thus it becomes a real advantage and can be done by every user who tries and uses it. With so many users applying it into the form of implementation in the form of software app in various functions and uses, it makes it difficult for end-users to evaluate and select the software application which creates a big problem for which end-users is right to determine the selection of the software application (Ayubi et al., 2015). Thus, we need an appropriate method that can be used to evaluate and select software app. There is a method that can help end-users, namely Multi-objective Optimization Ratio Analysis (MOORA). This method is one of the crystallizations of the Multi-criteria Decision Making (MCDM) (AytaçAdalı\&TuşIşık, 2017). Where the assessment is carried out with many criteria as an alternative determinant. This method can also be collaborated with other methods such as the price-quality ratio (Siahaan et al., 2017), (Kundakci, 2016)(Kundakci, 2016). The resulting ratio can be measured optimally according to the conditions of the budget that is owned, even though it is limited to providing optimal conditions, because the optimal is definitely the maximum but the maximum is not yet optimal.

The use of the MOORA method has two basic solutions, namely 1) Use that can be done without using a number of criteria or natural importance values, and 2) Using the value of importance, this value of importance is usually with the help of analytics such as the Hierarchy Process (AHP) Method (Saaty, 2009) ) give weight to each 
criterion reference value, AHP is the best way to give preference weight to each problem method, on the grounds that it is objective and not manually regulated without careful consideration. In this study the authors used the first basic solution, which is natural. So that the determination of preference weights becomes an independent form and is very objective. The connection with this research is not to use the value of importance but to directly determine the ratio system which leads to optimization and ranking values. From the discussion of this article in the future, we will try to develop using the eigenvector as a determinant of the criteria weights using the AHP method. So that the weight determination will be more objective through the help of a questionnaire instrument, but currently the authors only use natural solutions. In order to know more clearly the results obtained by natural solutions. It is better if we determine the weight using the given importance value objectively by using a questionnaire which estimates the number of respondents as many as 200 respondents, so that the results of decision support for the selection process of the app software. What is obtained is more objective and strong. Dengan demikian penetapan terhadap keputusan yang diambil berdasarkan nilai eigenvalue dari sebuah analisis akan lebih meyakinkan dan dapat dijadikan sebagai barameter penyeleksian terhadap software app.

\section{Multi-criteria Decision Making (MCDM)}

\section{LITERATURE REVIEW}

Multi-criteria Decision Making (MCDM) is a multi-criteria selection technique. The methods that are widely used by researchers (Saaty, 2010)for problems related to the ranking system are one-way, meaning that there is no inversely proportional assessment, so this MCDM needs a comparison process with other methods (Mill, 2011). The MOORA method is part of the MCDM method whose working context is almost similar to the SAW method where, but the MOORA method can be developed into a comparison that is said to be a ratio with a certain variable (Tian et al., 2017), in this study the MOORA method is compared with variables price, this means to provide the optimal value of an item which has a benefit value for an item compared to the price variable. This does not mean to get the maximum value but to get an item with an optimal value, meaning that the acquisition of an item seen from the many benefits with the costs incurred is directly proportional to the two. This is the concept of an MCDM solution that can provide many criteria and many alternatives (Sarkar et al., 2015), because things like this create many difficulties in solving decision analytical and decision science, so that MCDM is able to provide an open and accurate picture. For the purpose of selecting the app software, this study was conducted to compare the price criteria, whether there is a clear difference in the ranking caused by the price criteria, this is likely to result in significant differences in the effect of the price criteria, so that changes in ranking will be calculated as a result of not being included. or included in the calculation against the price criteria, this becomes interesting from the research conducted on the results obtained (Aytaç Adalı \& Tuş Işık, 2017). The treatment of the results obtained will be the best input for this research and even become a new finding that can be used as a guide to assess the selection process for application software and its effect on decision-making support so that it is more optimal and consistent in making decisions(Brauers \& Zavadskas, 2009), especially in the selection and selection process. evaluation of the product in the form of a software app.

\section{Multi-objective Optimization by Ratio Analysis (MOORA).}

The MOORA method has two solution approaches, where the approach that is often used is the first approach, namely by using the ratio system (Sarkar et al., 2015), while the second approach uses preferences which are seen from the importance of each criterion. The approach proposed is an approach using system ratios.This approach tends to determine the ratio to determine the optimization value (Kamila \& Helma, 2019)which is followed by ranking of a number of alternatives with several stages. The stages used with the MOORA method bind to the four methods or steps used(Kamila \& Helma, 2019), (Stanujkic et al., 2012), namely: 1) determine pairwise matrices as a determinant of row data, pay attention to Equation (1) for filling pairwise matrices Data processing on pairwise matrices can be in the form of quantitative data or qualitative data. In fact, both qualitative and quantitative data can be used in the form of collaborative data. Qualitative data must first be converted into quantitative data so that it can be calculated, 2) determine the ratio system (ratio calculation) where the alternative value of each value $i$ to objective $\mathrm{j}$ divided by the denominator value that represents all alternatives to goal $\mathrm{j}$ and each denominator objective is the square root of the addition of the alternative quantities from $i$ to $m$ towards the goal $j$ pay attention to Equation (2), 3) Calculation of the optimization value that can be done by adding up the benefits (benefits) $j$ to $\mathrm{g}$ then reducing the total cost (cost) $\mathrm{g}+1 \mathrm{up}$ to $\mathrm{n}$ for each alternative $\mathrm{i}$ where the total of the process is called the ratio system, consider Equation (3). There are times when the determination of the ratio value is based on the importance value of each criterion, where the value of each attribute must be multiplied by the weight of each criterion first, then determining the ratio value of each i for each row, this can be done by using Equation (4). 


$$
\begin{gathered}
X=\left[\begin{array}{cccc}
x_{11} & x_{21} & \cdots & x_{1, n} \\
x_{21} & x_{22} & \cdots & x_{2 n} \\
\vdots & \vdots & \ddots & x_{3 n} \\
x_{m, 1} & x_{m 2} & \ldots & x_{m n}
\end{array}\right] \\
X^{*}{ }_{(i, j)}=\frac{x_{(i, j)}}{\sqrt{\sum_{i=1}^{m} x^{2}(i, j)}} \\
Y^{i}=\sum_{j=1}^{g} x_{(i, j)}-\sum_{j=g+1}^{n} x_{(i, j)} \\
Y^{i}=\sum_{j=1}^{g} x_{(i, j)} W_{j} x_{(i, j)}-\sum_{g+1}^{n} w_{j} x_{(i, j)}
\end{gathered}
$$

\section{Price-Quality Ratio.}

The price-quality ratio approach is an objective method used to determine the quality to price ratio (Hidayatulloh \& Naf'an, 2018)or an appreciation for the value of the rupiah that has been issued to determine the optimal value for the quality obtained (Ijadi Maghsoodi et al., 2018). The formula can be used to determine the value of the price-quality ratio by paying attention (Equation-5) and is quite simple.

$$
\text { Value of Money }(\text { V fM })=\frac{\text { Quality }}{\text { Price }}
$$

\section{METHOD}

In this study, the price-quality of ratio is used to provide a value of appreciation for an object oriented programming (OOP) based software application that is collaborated with the MOORA method which compares the quality value of software app with prices (Gadakh, 2011) attached to the application.the software. The steps that can be taken to simplify the completion with the Moora method (Pérez-Domínguez et al., 2018), of course, can be poured into a Morra algorithm, there are seven steps that must be done using the Moora method, namely 1) making a dataset view as an illustration of the data to be processed by the Moora method, 2) arranging pairwise matrices to determine the layout of the data elements to be obtained into two-dimensional matrices, 3) describe the ratio in the form of ratios of each criterion to which the ratio will be determined, 4) determine the value of the optimization ratio and optimization of the pricing ratio from the normalization results for each software app. These are two different things that need to be understood more deeply. From this, you can find the beginning of the ranking for the app software product. 5) take a reference approach to see the results obtained in determining the ranking using the Morra method and the approach with the price quality ratio method. 6) ranking that can be compared between the use of the Moora method and the approach using the price quality ratio, so which one is the right one to take by not including the pricing criteria or by entering the pricing criteria, ranking in this case greatly determines the ranking decision for each of them. each app software. 7) With the completion of the calculation process using the moora method and the price quality ratio, pricing criteria are included or not included, it can be taken support for which decision to use, it turns out that the results of the process are very different by welcoming the arrival of pricing to the app's software rating. pay attention to fig. 1 .

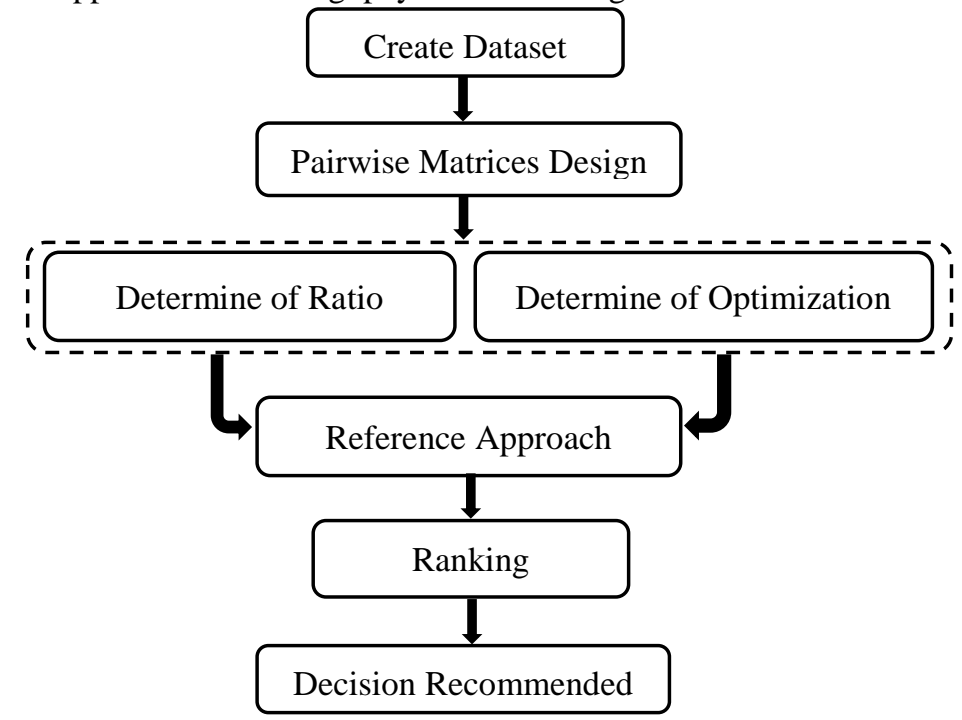

Fig. 1. MOORA Algorithm. 


\section{RESULT}

By paying attention to the MOORA algorithm, it is clear that there are several steps that must be taken to apply the MOORA method with the first concept, namely the ratio system. The first activity is to compile the dataset in the form of pairwise matrices, pay attention (Table-1), the second look for the system ratio value, the fourth determine the optimization of test results for software app, and the fifth is a preference approach to assign rankings and recommend it as support for decision making.

Table 1

Definition of Criteria

\begin{tabular}{cccc}
\hline \hline No. & Criteria Name & Criteria Code & Type \\
\hline 1 & Class structure & C1 & Benefit \\
\hline 2 & Inheritance & C2 & Benefit \\
\hline 3 & Encapsulation & C3 & Benefit \\
\hline 4 & Pollymorphys & C4 & Benefit \\
\hline 5 & Constructor & C5 & Benefit \\
\hline 6 & Accessor & C6 & Benefit \\
\hline 7 & Mutator & C7 & Benefit \\
\hline 8 & Visibility & C 8 & Benefit \\
\hline 9 & Overriding & C9 & Cost \\
\hline 10 & Overloading & C10 & Cost \\
\hline 11 & Price & C11 & Cost \\
\hline
\end{tabular}

Pay attention to the definition of the criteria shown in (Table-1) which is the definition of a number of criteria so that the data processing process becomes simpler and easier in reading the results of the process carried out, making it easier to write the process results so that the relationship between the criteria and the results can be seen.There are as many as eleven criteria that are accronymed and the type of each criterion.

Table 2

Dataset View

\begin{tabular}{|c|c|c|c|c|c|c|c|c|c|c|c|}
\hline Benefit Or Cost & $(+)$ & $(+)$ & $(+)$ & $(+)$ & $(+)$ & $(+)$ & $(+)$ & $(+)$ & $(-)$ & $(-)$ & $(-)$ \\
\hline $\begin{array}{c}\text { Criteria } \\
\text { Application (n) }\end{array}$ & $\mathrm{C} 1$ & $\mathrm{C} 2$ & $\mathrm{C} 3$ & $\mathrm{C} 4$ & $\mathrm{C} 5$ & C6 & $\mathrm{C} 7$ & $\mathrm{C} 8$ & C9 & $\mathrm{C} 10$ & $\mathrm{C} 11$ \\
\hline Appl-1 & 87 & 98 & 78 & 86 & 74 & 70 & 65 & 87 & 20 & 13 & 300 \\
\hline Appl-2 & 96 & 99 & 97 & 87 & 78 & 76 & 90 & 78 & 5 & 23 & 275 \\
\hline Appl-3 & 89 & 89 & 76 & 76 & 71 & 84 & 78 & 65 & 16 & 14 & 400 \\
\hline Appl-4 & 87 & 86 & 88 & 78 & 47 & 65 & 84 & 78 & 13 & 16 & 356 \\
\hline Appl-5 & 88 & 94 & 75 & 79 & 56 & 78 & 76 & 45 & 6 & 17 & 326 \\
\hline Appl-6 & 93 & 93 & 78 & 80 & 89 & 89 & 89 & 89 & 14 & 14 & 572 \\
\hline Appl-7 & 88 & 94 & 89 & 76 & 78 & 80 & 73 & 98 & 12 & 20 & 234 \\
\hline Appl-8 & 87 & 78 & 78 & 79 & 73 & 86 & 68 & 76 & 12 & 18 & 324 \\
\hline Appl-9 & 89 & 88 & 85 & 84 & 74 & 79 & 93 & 83 & 20 & 17 & 346 \\
\hline Appl-10 & 90 & 92 & 87 & 82 & 82 & 83 & 99 & 93 & 20 & 15 & 332 \\
\hline
\end{tabular}

By paying attention to (Table-2) that the data produced is a dataset obtained from the results of the assessment of ten app that have passed the selection of the college-level championship competition from the judges' assessment, then how to determine which application is the priority in the best ranking consisting of eleven barometers, Therefore, we need a method that is able to correct the multi-criteria concept and determine the best decision from a number of app with object-based assessments, so it is necessary to do a dataset by placing the weights. The ten app go through a normalization process (Table-3). Thus the results of the normalization process can be processed using a special method to determine application ratios either by determining price criteria or without price criteria, what will happen if prices are used as a comparison for software application products.

Table 3

Normalization View

\begin{tabular}{|c|c|c|c|c|c|c|c|c|c|c|c|}
\hline$\overline{\text { Ben }}$ & (+) & $(+(+)$ & $(+(+)$ & (+) & $(+)$ & $(+(+)$ & $(+(+)$ & $(+(+)$ & (-) & $(-)$ & $(-)$ \\
\hline 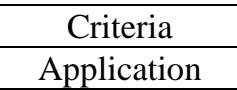 & $\mathrm{C} 1$ & $\mathrm{C} 2$ & 73 & $\mathrm{C} 4$ & C5 & C6 & C7 & C8 & C9 & $\mathrm{C} 10$ & $C_{1}$ \\
\hline Appl-1 & 0.31 & 0.31 & 0.30 & 0.34 & 0.32 & 0.28 & 0.25 & 0.34 & 0.43 & 0.24 & 0.22 \\
\hline
\end{tabular}




\begin{tabular}{cccccccccccc}
\hline Appl-2 & 0.34 & 0.34 & 0.37 & 0.34 & 0.32 & 0.30 & 0.35 & 0.31 & 0.11 & 0.43 & 0.25 \\
\hline Appl-3 & 0.31 & 0.31 & 0.29 & 0.30 & 0.30 & 0.33 & 0.30 & 0.26 & 0.34 & 0.26 & 0.36 \\
\hline Appl-4 & 0.31 & 0.31 & 0.33 & 0.31 & 0.20 & 0.26 & 0.32 & 0.31 & 0.28 & 0.30 & 0.32 \\
\hline Appl-5 & 0.31 & 0.31 & 0.28 & 0.31 & 0.34 & 0.31 & 0.29 & 0.18 & 0.13 & 0.32 & 0.29 \\
\hline Appl-6 & 0.33 & 0.32 & 0.30 & 0.31 & 0.28 & 0.35 & 0.34 & 0.35 & 0.30 & 0.26 & 0.48 \\
\hline Appl-7 & 0.31 & 0.33 & 0.34 & 0.31 & 0.33 & 0.32 & 0.28 & 0.38 & 0.26 & 0.37 & 0.21 \\
\hline Appl-8 & 0.31 & 0.27 & 0.30 & 0.31 & 0.31 & 0.34 & 0.26 & 0.30 & 0.26 & 0.34 & 0.29 \\
\hline Appl-9 & 0.31 & 0.30 & 0.32 & 0.33 & 0.36 & 0.32 & 0.36 & 0.33 & 0.43 & 0.32 & 0.31 \\
\hline Appl-10 & 0.32 & 0.32 & 0.33 & 0.32 & 0.35 & 0.33 & 0.38 & 0.37 & 0.43 & 0.28 & 0.30 \\
\hline
\end{tabular}

The next process that must be done is to determine the optimization value for each object-oriented software application by comparing the optimization ratio between entering the pricing criteria or determining the optimization value with the price as a comparison of the optimization ratio.

Table 4

Ranking of Application Software optimization values

\begin{tabular}{ccc}
\hline \hline Application Software & Nilai Optimasi & Ranking \\
\hline Appl-1 & 1.524 & 10 \\
\hline Appl-2 & 2.142 & 1 \\
\hline Appl-3 & 1.979 & 8 \\
\hline Appl-4 & 1.756 & 9 \\
\hline Appl-5 & 1.803 & 7 \\
\hline Appl-6 & 2.124 & 2 \\
\hline Appl-7 & 1.958 & 4 \\
\hline Appl-8 & 1.804 & 6 \\
\hline Appl-9 & 1.881 & 5 \\
\hline Appl-10 & 2.005 & 3 \\
\hline
\end{tabular}

Note (Table-4) which illustrates that the resulting optimization value involves a price criterion of eleven criteria which is the measurement, meaning that the criteria with a benefit and cost characteristic are all included in determining the value of the ratio, and those shown in (Table-5) are the same.as described in (Table-4) but price has an important role in determining the optimal ratio value, so that the presence of pricing criteria here results in global changes to the ranking system, meaning that the determination of an optimistic decision has been obtained, thus the optimal value that is owned byThe selected software application has the highest ratio value.Note (Table$5)$.

Table 5

Ranking of Application Software optimization valueswith pricing

\begin{tabular}{cccc}
\hline \hline Ranking & $\begin{array}{c}\text { Application } \\
\text { Software }\end{array}$ & $\begin{array}{c}\text { Pricing } \\
\text { (Juta-Rp) }\end{array}$ & Nilai Optimasi \\
\hline 1 & Appl-2 & 275 & 2.142 \\
\hline 2 & Appl-6 & 532 & 2.124 \\
\hline 3 & Appl-10 & 332 & 2.005 \\
\hline 4 & Appl-7 & 234 & 1.958 \\
\hline 5 & Appl-9 & 346 & 1.881 \\
\hline 6 & Appl-8 & 324 & 1.804 \\
\hline 7 & Appl-5 & 326 & 1.803 \\
\hline 8 & Appl-3 & 400 & 1.797 \\
\hline 9 & Appl-4 & 356 & 1.756 \\
\hline 10 & Appl-1 & 300 & 1.524 \\
\hline
\end{tabular}

In stark contrast to the understanding contained in (Table-4) and (Table-5), where the optimization value process does not include pricing criteria in the ratio calculation process and pricing criteria are used as a comparison in determining the assessment of object-based software app, so that it has differences.very sharp in determining the assessment of the software application, this is clearly the optimal choice of software app.Note (Table-6) and (Table-7) the following. 
Table 6

Value of Application Software Optimization without pricing

\begin{tabular}{cccc}
\hline \hline $\begin{array}{c}\text { Application } \\
\text { Software }\end{array}$ & Nilai Optimasi & $\begin{array}{c}\text { Price Quality } \\
\text { Ratio }\end{array}$ & Ranking \\
\hline Appl-1 & 1.524 & 6.635 & 4 \\
\hline Appl-2 & 2.142 & 8.645 & 2 \\
\hline Appl-3 & 1.979 & 4.985 & 9 \\
\hline Appl-4 & 1.756 & 5.473 & 8 \\
\hline Appl-5 & 1.803 & 6.138 & 6 \\
\hline Appl-6 & 2.124 & 4.431 & 10 \\
\hline Appl-7 & 1.958 & 9.286 & 1 \\
\hline Appl-8 & 1.804 & 6.177 & 5 \\
\hline Appl-9 & 1.881 & 6.032 & 3 \\
\hline Appl-10 & 2.005 & 6.702 & \\
\hline
\end{tabular}

After determining the price, there will be major changes where the price criteria have a very important role in determining the software application to become a selection and evaluation process that provides optimal choices in determining decision support.Thus, the determination of the value of the quality-price ratio will be used as a decision that provides instructions for the user to choose a software application product that has an optimum value.Note (Table-7) the following.

Table 7

Ranking of application software optimization value with price-quality ratio

\begin{tabular}{ccccc}
\hline \hline Ranking & $\begin{array}{c}\text { Application } \\
\text { Software }\end{array}$ & $\begin{array}{c}\text { Pricing } \\
\text { (Juta-Rp) }\end{array}$ & Nilai Optimasi & $\begin{array}{c}\text { Price Quality } \\
\text { Ratio }\end{array}$ \\
\hline 1 & Appl-7 & 326 & 1.958 & 9.286 \\
\hline 2 & Appl-2 & 532 & 2.142 & 8.645 \\
\hline 3 & Appl-10 & 300 & 2.005 & 6.702 \\
\hline 4 & Appl-1 & 275 & 1.524 & 6.635 \\
\hline 5 & Appl-8 & 400 & 1.804 & 6.177 \\
\hline 6 & Appl-5 & 346 & 1.803 & 6.138 \\
\hline 7 & Appl-9 & 356 & 1.881 & 6.032 \\
\hline 8 & Appl-4 & 234 & 1.756 & 5.473 \\
\hline 9 & Appl-3 & 332 & 1.797 & 4.985 \\
\hline 10 & Appl-6 & 324 & 2.124 & 4.431 \\
\hline
\end{tabular}

By paying attention to the changes in the tables above, it is seen that to determine the value of the optimization on the effect of price, it is seen that it is very influential in determining the value of optimization in selecting and evaluating the product of this software application.In the calculation process using the MOORA method, it is very influential in determining the optimum value of this application software product.This means that the user is expected to take advantage of this method to obtain the product in an optimal way, meaning that the amount of costs that are owned by the acquisition of software app in this case is very supportive in getting a very optimal value.

\section{DISCUSSIONS}

The use of the MOORA method is the best way to determine the evaluation and selection process, because it is part of the multi-criteria concept that uses many criteria, which requires that the MOORA method also takes into account the types of criteria that can provide benefit values and also cost values (costs), which needs to be considered once in determining the value of the ratio using this method is whether the assessment of the price quality ratio against pricing needs to be placed in it or removed from the table.If put in the table it doesn't seem right, because the value is getting bigger.Thus, if we want to use the benefit ratio, the price criteria should be excluded from the calculation table.

\section{CONCLUSION}

Determining the optimization value of object-based software app is a way that can be done to obtain the optimum value of acquisition, and if it includes this price criterion, it has a major change in determining the ranking system. Unlike the case with including a preference for the weight of the criterion, this must be combined with other methods that are able to determine the weight value of each criterion, and usually the preference weight value 
is done in many ways and must use an appropriate method and should not be done in a way. set at will. The final results obtained from the analysis provide an illustration that if the price criteria are included in the process of calculating the Appl-2 price quality ratio, the role holder is the ranking, whereas if the price criteria are issued in the process, then the person holding the role as the ranking is controlled by Appl-7. who became the first rank. Thus, a better process for determining the price quality ratio, the price criteria should be outside the calculation and should be a comparison to the benefits, so that it becomes an optimal decision.

\section{ACKNOWLEDGMENT}

Thank you to my family who want to support in this research process which is very helpful both morally and materially, then to other parties I do not forget to thank STMIK Nusa Mandiri for providing support in the form of motivation to write this article, and the publishing party from the editorial staff.who are willing to accept this article even though it is in such a careful process in selecting the topic until this article is published.

\section{REFERENCES}

Aytaç Adalı, E., \& Tuş Işık, A. (2017). The multi-objective decision making methods based on MULTIMOORA and MOOSRA for the laptop selection problem. Journal of Industrial Engineering International, 13(2), 229237. https://doi.org/10.1007/s40092-016-0175-5

Ayubi, A., Muqtadiroh, F. A., \& Nisafani, A. S. (2015). Quality Measurement Of Object Oriented Code Using Chidamber And Kemerer Metric In Tthe Perspective Of Maintainabality, Efficiency, Understadability And Replaceability (Case Studies Software Accounting XYZ).

Brauers, W. K., \& Zavadskas, E. K. (2009). Robustness of the multi-objective moora method with a test for the facilities sector. Technological and Economic Development of Economy, 15(2), 352-375. https://doi.org/10.3846/1392-8619.2009.15.352-375

Gadakh, V. (2011). Application of MOORA method for parametric optimization of milling process. International Journal of Applied Engineering Research, 1(4), 743-758.

Hidayatulloh, I., \& Naf'an, M. Z. (2018). Integrasi Sentiment Analysis SentiWordNet pada Metode MOORA untuk Rekomendasi Pemilihan Smartphone. Jurnal Nasional Teknik Elektro Dan Teknologi Informasi (JNTETI), 7(1), 21-26. https://doi.org/10.22146/jnteti.v7i1.396

Ijadi Maghsoodi, A., Abouhamzeh, G., Khalilzadeh, M., \& Zavadskas, E. K. (2018). Ranking and selecting the best performance appraisal method using the MULTIMOORA approach integrated Shannon's entropy. Frontiers of Business Research in China, 12(1), 1-21. https://doi.org/10.1186/s11782-017-0022-6

Kamila, I., \& Helma, S. S. (2019). Implementation of MOORA Method for Determining Prospective Smart Indonesia Program Funds Recipients. International Journal of Engineering and Advanced Technology, 9(2), 1920-1925. https://doi.org/10.35940/ijeat.b2860.129219

Kundakci, N. (2016). Combined Multi-Criteria Decision Making Approach Based On Macbeth And MultiMOORA Methods. Alphanumeric Journal, 4(1). https://doi.org/10.17093/aj.2016.4.1.5000178402

Mill, R. B. (2011). Validity of the Ahp / Anp : Comparing Apples and. International Journal of the Analitical Hierachy Process, 3(1), 2-27.

Pérez-Domínguez, L., Sánchez Mojica, K. Y., Ovalles Pabón, L. C., \& Cordero Diáz, M. C. (2018). Application of the MOORA method for the evaluation of the industrial maintenance system. Journal of Physics: Conference Series, 1126(1), 1-6. https://doi.org/10.1088/1742-6596/1126/1/012018

Prasetyo, H., \& Sutopo, W. (2018). Industri 4.0: Telaah Klasifikasi Aspek Dan Arah Perkembangan Riset. J@ti Undip : Jurnal Teknik Industri, 13(1), 17. https://doi.org/10.14710/jati.13.1.17-26

Saaty, T. L. (2010). The Eigenvector In Lay Language 2 . What we learn when we have measurement. 2(2), 163169.

Sarkar, A., Panja, S. C., Das, D., \& Sarkar, B. (2015). Developing an efficient decision support system for nontraditional machine selection: an application of MOORA and MOOSRA. Production and Manufacturing Research, 3(1), 324-342. https://doi.org/10.1080/21693277.2014.895688

Siahaan, A. P. U., Rahim, R., \& Mesran, M. (2017). Student Admission Assesment using Multi-Objective Optimization on the Basis of Ratio Analysis. International Seminar IRSTC 2017, Irstc. https://doi.org/10.31219/osf.io/cwfpu

Stanujkic, D., Magdalinovic, N., Stojanovic, S., \& Jovanovic, R. (2012). Extension of ratio system part of MOORA method for solving decision-making problems with interval data. Informatica, 23(1), 141-154. https://doi.org/10.15388/informatica.2012.353

Tian, Z. peng, Wang, J., Wang, J. qiang, \& Zhang, H. yu. (2017). An improved MULTIMOORA approach for multi-criteria decision-making based on interdependent inputs of simplified neutrosophic linguistic information. Neural Computing and Applications, 28, 585-597. https://doi.org/10.1007/s00521-016-2378-5 